\title{
Small cell lung cancer with positive anti-Hu antibodies presenting as gastroparesis
}

\author{
David N Moskovitz MD BSc, Kenneth V Robb MD FRCPC
}

DN Moskovitz, KV Robb. Small cell lung cancer with positive anti-Hu antibodies presenting as gastroparesis. Can J Gastroenterol 2002;16(3):171-174.

Lung cancer is the most common cancer in North America. Small cell lung cancer (SCLC) represents $15 \%$ to $25 \%$ of lung cancers. SCLC commonly relapses, resulting in a $3 \%$ to $8 \%$ fiveyear survival rate. The poor prognosis associated with SCLC is partly due to late diagnosis of the disease. Paraneoplastic syndromes can be early manifestations of SCLC. The potential benefit of early diagnosis has prompted investigations into markers of this disease. Some patients may present with predominantly gastrointestinal dysmotility symptoms that have no obvious explanation. Testing for anti-Hu antibodies, as a valuable marker of SCLC, should be considered in the investigation. A case of SCLC with positive anti-Hu antibodies presenting with intestinal pseudo-obstruction is presented. Gastrointestinal dysmotility as a manifestation of paraneoplastic syndrome is reviewed.

Key Words: Antinuclear antibodies; Hypomotility; Paraneoplastic syndrome; Small cell lung cancer
Cancer du poumon à petites cellules, accompagné d'anticorps anti-Hu se présentant sous forme de gastroparésie

RÉSUMÉ : Le cancer du poumon, dont 15 à $25 \%$ des cas sont des cancers du poumon à petites cellules (CPPC), est la forme de cancer la plus répandue en Amérique du Nord. Le CPPC donne souvent lieu à des rechutes, d'où un taux de survie de 3 à $8 \%$ au bout de cinq ans. Le sombre pronostic de la maladie est en partie attribuable à son diagnostic tardif. Les syndromes paranéoplasiques peuvent être des manifestations précoces du CPPC. Les avantages possibles d'un diagnostic précoce a poussé les chercheurs à trouver des marqueurs de la maladie. Certains patients peuvent présenter surtout des symptômes de dysmotilité gastrointestinale, sans cause apparente. La recherche d'anticorps anti-Hu comme marqueur valable de CPPC devrait être envisagée chez ces patients. Voici un cas de CPPC, accompagné d'anticorps anti-Hu, se présentant sous forme de pseudo-obstruction intestinale. Il sera donc question dans le présent article de dysmotilité gastro-intestinale comme manifestation d'un syndrome paranéoplasique.

Department of Medicine, University of Toronto, and University Health Network and Mount Sinai Hospital, Toronto, Ontario

Correspondence and reprints: Dr David N Moskovitz clo Dr Kenneth V Robb, 399 Bathurst Street, 8 East \#514, Toronto, Ontario M5T 2 S8.

Telephone 416-603-6467

Received for publication October 4, 2001. Accepted January 18, 2002 
$\mathrm{P}$ araneoplastic syndromes result from the distant effects of underlying malignancy, and are not related to the local effects of the primary tumour or its metastases. Paraneoplastic neurological syndromes may affect any part of the nervous system. The most common neurological syndromes are paraneoplastic sensory neuropathy and paraneoplastic encephalomyelitis (1). Other manifestations include cerebellar ataxia, limbic encephalitis, polyradiculopathy, associated Lambert-Eaton myasthenic syndrome, myopathy and a multitude of gastrointestinal syndromes including gastroparesis, pseudo-obstruction, esophageal achalasia and other dysmotilities. The onset of these paraneoplastic syndromes typically precedes tumour diagnosis. Seropositivity for type 1 antineuronal nuclear autoantibodies (ANNA-1 or anti-Hu antibodies) is a marker of small cell lung carcinoma (SCLC) in patients who present with paraneoplastic symptoms.

A patient whose presenting features were solely or entirely related to gastroparesis is described. The patient tested positive for anti-Hu antibodies, and SCLC was ultimately diagnosed.

\section{CASE PRESENTATION}

A 57-year-old woman with a six-month history of weight loss was transferred to the authors' facility for further investigations. She was previously well, with no specific gastrointestinal illnesses. Past medical history was significant for Graves' disease, which had been treated with thyroidectomy and thyroid replacement therapy. Her thyroid disease was under control. Diabetes was not present. Her medications on transfer included thyroxine $0.05 \mathrm{mg}$ taken orally once a day, docusate sodium $100 \mathrm{mg}$ taken orally bid, domperidone $20 \mathrm{mg}$ taken orally with meals, lactulose $30 \mathrm{~mL}$ taken orally each night, dimenhydrinate 25 to $50 \mathrm{mg}$ taken intravenously or intramuscularly every 4 to $6 \mathrm{~h}$ as required and metoclopramide $5 \mathrm{mg}$ taken intravenously every $6 \mathrm{~h}$. The patient had a 40 pack-year history of smoking. She did not consume any alcohol. She had lost $23 \mathrm{~kg}$ of body weight, associated with severe constipation, nausea and vomiting, and she eventually became intolerant to oral foods. Further questioning revealed a several month history of a sensory neuropathy with glove and stocking distribution. She denied any fever. The rest of the functional inquiry was unremarkable. Physical examination revealed cachexia, with marked temporalis wasting. Her heart rate was 84 beats/min, blood pressure 130/60 $\mathrm{mmHg}$, respiratory rate 16 breaths/min, temperature $36.1^{\circ} \mathrm{C}$ and oxygen saturation $97 \%$ on room air. Cardiac and respiratory examinations were normal. There was no clubbing, and there were no bowel sounds. The abdomen was soft and nontender, with no hepatosplenomegaly or masses. Cranial nerves 2 to 12 were normal. Motor examination revealed no focal abnormalities, other than some general weakness likely related to her cachexia. Reflexes were equal bilaterally, and there was normal tone. Sensory examination showed decreased sensation to light touch, pin-prick, and vibration in the arms and legs bilaterally. Coordination was normal.
There was no other clinical evidence of autonomic neuropathy. Investigation in hospital revealed that her thyroid function was normal. The chest x-ray was normal. Gastric motility studies demonstrated severely delayed gastric emptying, with a half-time of greater than 293 min. After trying multiple gastric motility agents, she finally required total parenteral nutrition. Electromyography studies confirmed a diffuse sensory polyneuropathy. A computed tomography scan of the thorax showed enlarged hilar lymph nodes with normal lung parenchyma. Mediastinoscopy with subcarinal node biopsy revealed small cell anaplastic carcinoma. Tests from the laboratory at the University of Arkansas Medical Services, Fayetteville, were positive for anti-Hu (antineuronal nuclear antibodies). Two serum samples from the patient were examined by immunohistochemistry, Western blot of purified human neuronal proteins and Western blot of $\mathrm{HuD}$ recombinant protein. The techniques used were similar to those reported by Szabo et al (2). All tests were positive for anti-Hu antibodies, and all assays were done using sera dilutions of 1:1000. The patient remained resistant to the concurrent use of two antiemetics (dimenhydrinate, prochlorperazine), two motility agents (metoclopramide, domperidone), one stool softener (docusate sodium) and one anticholinesterase agent (pyridostigmine bromide), and required ongoing total parenteral nutrition. She was transferred to a local cancer centre to receive definitive chemotherapy for her SCLC. The patient was started on a chemotherapy combination of carboplatinum and etoposide. There were no complications of the chemotherapy treatment. She was continued on chemotherapy treatment and a three-week course of local radiation treatment. After five months of follow-up, there had been no change in her clinical status.

\section{DISCUSSION}

Paraneoplastic syndromes are disorders that result from the distant effects of an underlying malignancy, and are not related to the local effects of the primary tumour or its metastases. In the majority of patients with gastrointestinal manifestations, the evolution of symptoms and signs is subacute (less than six months). Reports of symptoms developing over $24 \mathrm{~h}$, however, have been documented, the mean latency between presentation and tumour diagnosis being between eight and 12 months (3). Gastroparesis and intestinal pseudo-obstruction are known manifestations of the paraneoplastic syndrome associated with SCLC (4). The most common gastrointestinal manifestations of the paraneoplastic syndrome are reported in Table 1 (3). It is important to recognize gastrointestinal symptoms because they precede oncological diagnosis and are the presenting symptoms in the majority of cases. Dysmotility syndromes are often accompanied by other paraneoplastic manifestations. Most commonly, patients present with neuropathy (40\%) (sensory, mixed somatic, autonomic, motor). Cerebellar symptoms ( $10 \%$ to $20 \%$ ), limbic encephalitis (10\% to $20 \%$ ) (seizures, cognitive disturbance), cranial neuropathies (15\%), myelopathies (2\%), myopathies (5\%) and associa- 
tions with the Lambert-Eaton syndrome $(5 \%)$ have been reported. SCLC is the usual neoplasm associated with the syndrome of paraneoplastic chronic intestinal pseudoobstruction $(5,6)$. In one study of 162 patients identified as being anti-Hu positive, $81 \%$ had SCLC (3). However, there have been reports of paraneoplastic syndromes with renal cell carcinoma, prostate carcinoma, breast carcinoma, bladder carcinoma, ovarian carcinoma, choroid papilloma, lymphoma and cervical carcinoma $(3,7,8)$.

The association of anti-Hu and pseudo-obstruction was demonstrated in 1993 (9). Since then, studies have shown an association between anti-Hu and other gastrointestinal manifestations, including gastroparesis, esophageal achalasia and dysphagia (3). In one study (3), the investigators looked at the spectrum of symptoms and signs in adults with cancer who were positive for anti-Hu antibodies; 19 of 162 patients $(12 \%)$ initially presented to their gastroenterologist with symptoms of gut dysmotility. In all cases, SCLC was ultimately diagnosed. In the same study, 38 patients (23\%) developed gastrointestinal dysmotility over the course of their illness. This study concluded that, for the clinical gastroenterologist, paraneoplastic autoimmune serological testing offers a valuable diagnostic aid for determining the likelihood of an underlying SCLC in patients presenting with unexplained gastrointestinal dysmotility disorders. These results are consistent with our presented case. While not available in Canada, measurement of antibodies is available at centres in the United States, including the Mayo Clinic and University of Arkansas. More recently, one study suggested a high seropositivity of serological testing for the diagnosis of an underlying malignancy in the absence of negative imaging studies (10). Lee et al (10) suggested that positive serological testing including ANNA-1, type 1 Purkinje cell cytoplasmic antibody or $\mathrm{N}$-type calcium channel binding antibodies (all different terms for various forms of anti-Hu antibodies) in patients with unexplained gastrointestinal symptoms should prompt further evaluation for a malignant process. It can be concluded that a panel of paraneoplastic serological tests serves as a useful initial step in patients with a high clinical suspicion.

The principle $\mathrm{Hu}$ antigens in humans are $\mathrm{HuD}, \mathrm{HuC}$, and Hel-N1. Hu antigens are 35 to $40 \mathrm{kD}$ proteins expressed both in the nucleus and in the cytoplasm of all neurons of the central and peripheral nervous system, as well as in tumour tissue (11). The antibody received the name $\mathrm{Hu}$ from the first two letters of the original index patient's last name. The function of $\mathrm{Hu}$ proteins is unknown; however, it has been postulated that they act as transfactors involved in selective mRNA degradation and promote differentiation of the neuronal phenotype (12). The two assays for the detection of $\mathrm{Hu}$ antibodies include immunohistochemistry (13) and Western blot analysis (14). One study reported a specificity of $99 \%$ and a sensitivity of $82 \%$ in detecting paraneoplastic syndromes (15). One study (16) found a $10 \%$ rate of false-positive anti-Hu results using immunohistochemistry. The titres of Hu anti-

\section{TABLE 1} Common gastrointestinal manifestations of the
paraneoplastic syndrome

\begin{tabular}{lc}
\hline Symptom & Rate of occurrence (\%) \\
\hline Gastroparesis & 50 \\
Pseudo-obstruction & 21 \\
Dysphagia & 11 \\
Esophageal achalasia & 11 \\
Pyloric stenosis & 5 \\
Anal spasticity & 3 \\
\hline
\end{tabular}

Data from reference 3

bodies have been shown to correlate with the presence of paraneoplastic syndrome. Titres greater than 1:1000 are associated with paraneoplastic syndromes (12).

The pathogenesis of paraneoplastic neurological syndromes is incompletely understood. One hypothesis explaining paraneoplastic visceral neuropathy is infection. Another more plausible mechanism of pathogenesis is autoimmunity. Studies have demonstrated antibodies to neural tissue in the sera of patients with SCLC who experienced paraneoplastic symptoms (17-21). Tumour-associated antigens found in or on the surface of human SCLC cells, but not on normal lung tissue, cross-react with normal nervous system tissue. Examples include autoantibodies to the nuclei of neurons of dorsal root ganglia in patients with SCLC having subacute sensory neuropathy. It has also been hypothesized, through embryological studies, that all amine precursor uptake and decarboxylation cells of the bronchopulmonary and gastroenteropancreatic axis have a common origin (22-25). It has, therefore, been suggested that neural tissues and SCLC that share a common embryological origin have the potential to express similar antigens. As a result, an immune cell response to the tumour could crossreact with the central, peripheral and enteric nervous systems. If localized to the myenteric plexus, gastrointestinal motor dysfunction would be the primary manifestation. Finally, there is circumstantial evidence to suggest that $\mathrm{T}$ cell-mediated mechanisms play a major pathogenic role. This is suggested by the inflammatory infiltration of mononuclear cells in areas of the nervous system that are symptomatic.

Unfortunately, the management of patients with SCLC and paraneoplastic syndrome has been difficult. The use of steroids, plasma exchange and intravenous immunoglobulin has been found to be unsuccessful (3). The hypothesis that the gastrointestinal manifestations associated with the paraneoplastic syndrome are caused by an autoimmune process has prompted the use of immunosuppressants. While there have been reports of improvement with intravenous immunoglobulin therapy, the general response has been poor. There have been documented responses to treatment with chemotherapeutic agents (26). In general, the treatment of the gastrointestinal manifestations focuses on treating the primary malignancy (27). However, there have 
been no reports showing improvement with the treatment of the underlying SCLC. Therefore, the management of gastrointestinal symptoms is mainly supportive. Management focuses on nutrition, prokinetic agents and consideration for surgery. Oral or enteral nutrition is typically used for neuropathic disorders, while parenteral nutrition may be necessary in patients with severe dysmotility. Prokinetic agents include erythromycin, metoclopramide, octreotide, neostigmine and 5-hydroxytryptamine ${ }_{4}$ agonists. A surgical role in intestinal dysmotility is predominantly to resect or bypass localized disease.

\section{SUMMARY}

SCLC typically presents at an advanced stage with large hilar masses and mediastinal adenopathy. Patients can present earlier with a paraneoplastic syndrome. The most common neurological syndromes associated with SCLC are paraneoplastic sensory neuropathy and encephalomyelitis. Though less common, patients may present with predominantly gastrointestinal symptoms, as in our patient. A significant unexplained gastroparesis should prompt the physician to consider anti-Hu antibodies and SCLC.

\section{REFERENCES}

1. Henson RA, Urich H. Cancer and the Nervous System: The Neurological Manifestation of Systemic Malignant Disease. Oxford: Blackwell, 1982.

2. Szabo A, Dalmau J, Manley G, et al. $\mathrm{HuD}$ a paraneoplastic encephalomyelitis antigen contains RNA-binding domains and is homologous to elav and sex lethal. Cell 1991;67:325-33.

3. Lucchinetti CF, Kimmel DW, Lennon VA. Paraneoplastic and oncologic profiles of patients seropositive for type 1 antineuronal nuclear autoantibodies. Neurology 1998;50:652-7.

4. Schuffler MD, Baird WH, Fleming RC, et al. Intestinal pseudoobstruction as the presenting manifestation of small-cell carcinoma of the lung. Ann Intern Med 1983;98:129-34.

5. Green D, Joynt RJ, Van Allen MW. Neuromyopathy associated with a malignant carcinoid tumor - a case report. Arch Intern Med 1964;114:494-6

6. Sipila R, Leinonen H, Juntunen J. Paraneoplastic polyneuropathy associated with a carcinoid tumor of the cecum. Acta Med Scand 1982;212:183-4.

7. Chinn JS, Schuffler MD. Paraneoplastic visceral neuropathy as a cause of severe gastrointestinal motor dysfunction. Gastroenterology 1988;95:1279-86.

8. Lennon VA, Sas DF, Busk MF, et al. Enteric neuronal autoantibodies in pseudo-obstruction with small-cell lung carcinoma. Gastroenterology 1991;100:137-42.

9. Condom E, Vidal A, Rota R, Graus F, Dalmau J, Ferrer I. Paraneoplastic intestinal pseudo-obstruction associated with high titres of $\mathrm{Hu}$ autoantibodies. Virchows Arch A Pathol Anat Histopathol 1993;423:507-11.

10. Lee HR, Lennon VA, Camilleri M, Prather CM. Paraneoplastic gastrointestinal motor dysfunction: Clinical and laboratory characteristics. Am J Gastroenterol 2001;96:373-9.

11. Dalmau J, Furneaux HM, Rosenblum MK, Graus F, Posner JB. Detection of the anti-Hu antibody in specific regions of the nervous system and tumor from patients with paraneoplastic encephalomyelitis/sensory neuropathy. Neurology 1991;41:1757-64.

12. Senties-Madrid H, Vega-Boada F. Paraneoplastic syndromes associated with anti-Hu antibodies. Isr Med Assoc J 2001;3:94-103.

13. Graus F, Ribalta T, Campo E, Monforte R, Urbano A, Rozman C. Immunohistochemical analysis of the immune reaction in the nervous system in paraneoplastic encephalomyelitis. Neurology 1990;40:219-22.

14. Dalmau J, Furneaux HM, Gralla RJ, Kris MG, Posner JB. Detection of the anti-Hu antibody in the serum of patents with small cell lung cancer - A quantitative Western blot analysis. Ann Neurol 1990;27:544-52.

15. Molinuevo JL, Graus F, Serrano C, Rene R, Guerrero A, Illa I. Utility of anti-Hu antibodies in the diagnosis of paraneoplastic sensory neuropathy. Ann Neurol 1998;44:976-80.

16. Loblad KO, Boucraut J, Bourdenet S, et al. Sensory neuronopathy and small cell lung cancer: antineuronal antibody reacting with neuroblastoma cells. J Neurol 1993;240:327-32.

17. Greenlee JE, Lipton HL. Anticerebellar antibodies in serum and cerebrospinal fluid of a patient with oat cell carcinoma of the lung and paraneoplastic cerebellar degeneration. Ann Neurol 1986;19:82-5.

18. Jaeckle KA, Graus F, Houghton A, et al. Autoimmune response of patients with paraneoplastic cerebellar degeneration to a Purkinje cell cytoplasmic protein antigen. Ann Neurol 1985;18:592-600.

19. Grunwald GB, Simmonds MA, Klein R, Kornguth SE. Autoimmune basis for visual paraneoplastic syndrome in patients with small cell lung carcinoma. Lancet 1985;i:658-61.

20. Graus F, Elkon KB, Cordon-Cardo C, Posner JB. Sensory neuropathy and small cell lung cancer-antineurol antibody that also reacts with the tumor. Am J Med 1986;80:45-52.

21. Babikian V, Stefansson K, Marton LS, Liebermann F, Arnason BGW. Antibodies against antigens shared by an oat-cell tumor and neuro tissue in the serum of a patient with paraneoplastic disorder of peripheral nerve and spinal cord. Neurology 1984;37(Suppl 1):186.

22. Sidhu GS. The endodermal origin of digestive and respiratory tract APUD cells. Am J Pathol 1979;96:5-20.

23. Gould VE, Linnoila RI, Memoli VA, Warren WH. Neuroendocrine components of the bronchopulmonary tract: hyperplasia, dysplasias, and neoplasms. Lab Invest 1983;49:519-37.

24. Gould VE, Linnoila RI, Memoli VA, Warren WH. Neuroendocrine cells and neuroendocrine neoplasms of the lung. Pathol Annu 1983;18:287-330.

25. Pearse AGE, Takor TT. Embryology of the diffuse neuroendocrine system and its relationship to the common peptides. Fed Proc 1979;38:2288-94.

26. Graus F, Vega F, Delattre JY, et al. Plasmapharesis and antineoplastic treatment in CNS paraneoplastic syndromes with antineuronal antibodies. Neurology 1992;42:536-40.

27. Anderson NE, Cunningham JM, Posner JB. Autoimmune pathogenesis in paraneoplastic syndrome associated with small cell lung cancer. Neurology 1988;38:1391. 


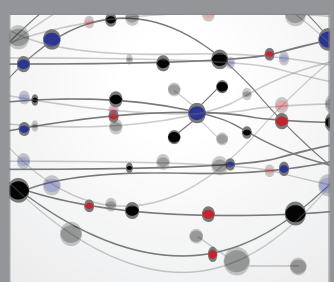

The Scientific World Journal
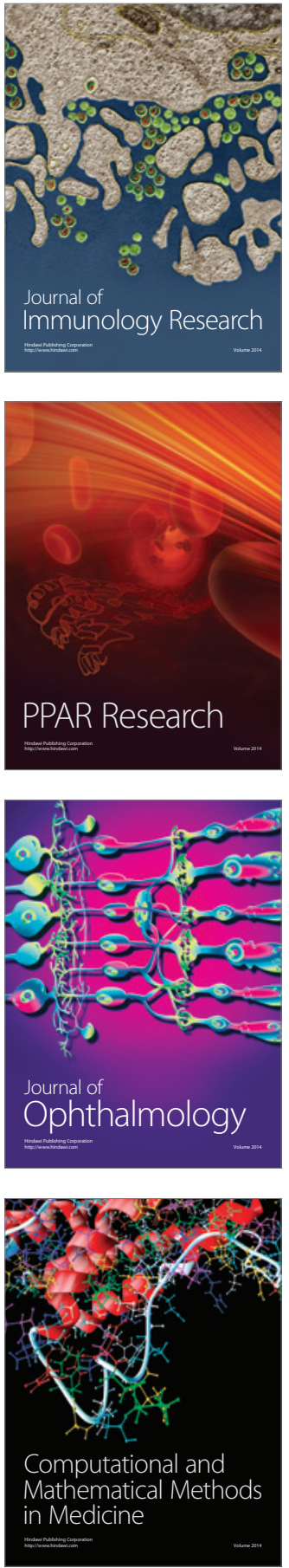

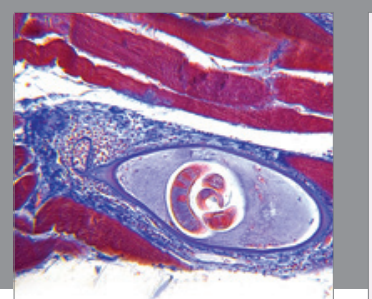

Gastroenterology Research and Practice

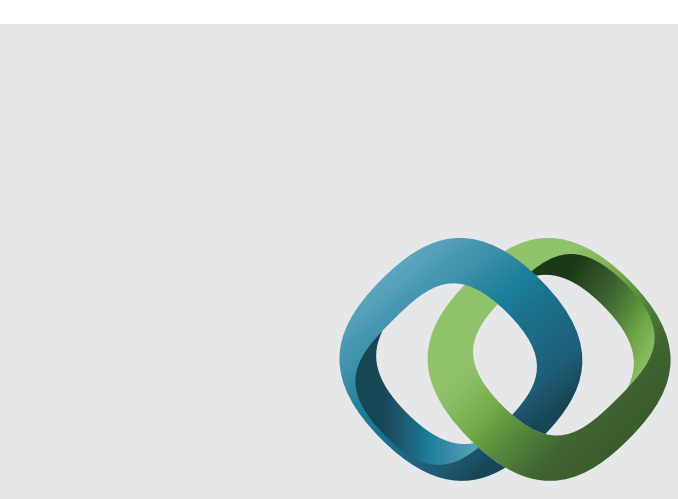

\section{Hindawi}

Submit your manuscripts at

http://www.hindawi.com
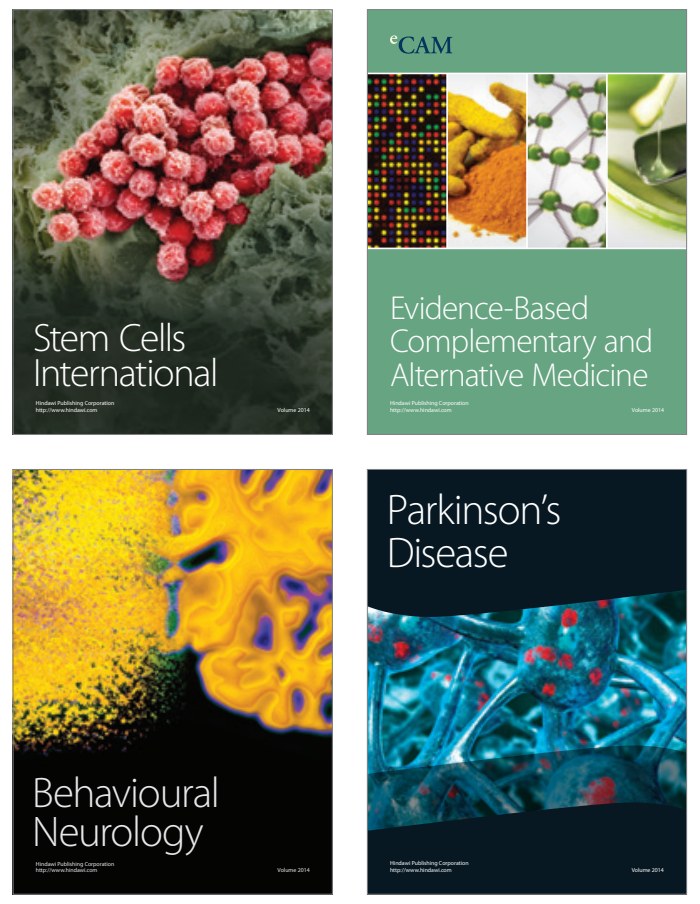
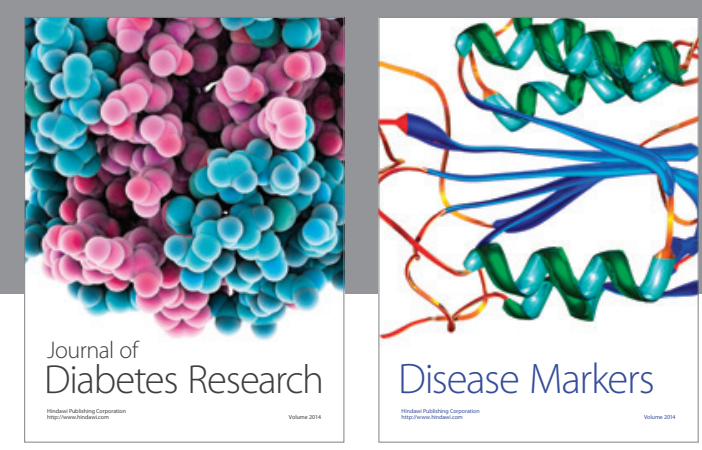

Disease Markers
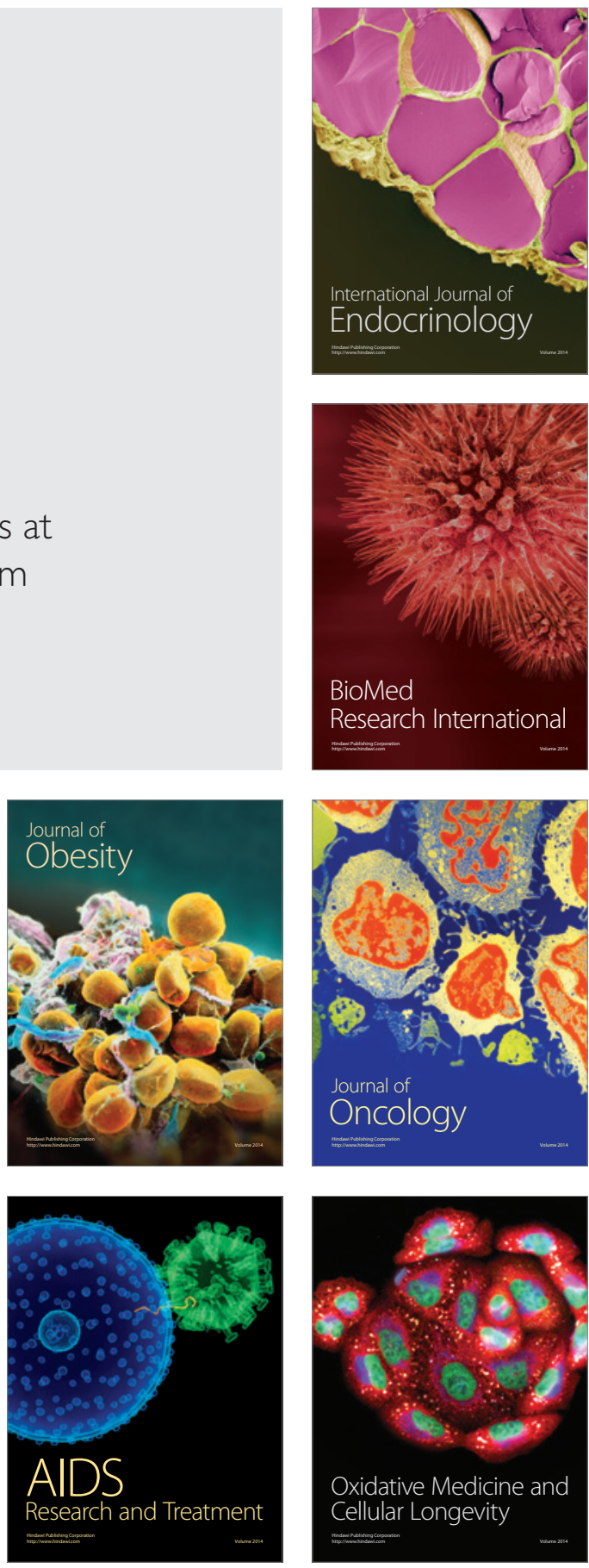